\title{
Can Growth of a Trading Partner Harm a Country?
}

\author{
Kwok Tong Soo \\ Lancaster University
}

\begin{abstract}
Can growth of a trading partner harm a country? This paper seeks to answer this question through the use of an eclectic trade model which is similar in flavour to Markusen (1986). This paper makes two contributions. First, it develops a simple and tractable model of international trade based on a combination of imperfect competition, comparative advantage, and identical but non-homothetic preferences in a three country framework. Second, it uses this framework to consider the possibility of losses from partner-country growth in a free-trading environment. We find that the presence of nonhomothetic preferences in particular, leads to a home bias in consumption which dampens any negative welfare effects when a country's trading partners grow.
\end{abstract}

- JEL classification: F12, F14

- Keywords: International trade, Three countries, Non-homothetic preferences

\section{Introduction}

Since the early 1990s, China and India have emerged as the fastest-growing economies in the world. Their rapid growth has inspired much debate and speculation in the media. For example, analysts at Goldman Sachs (Wilson and Purushothaman (2003)) predict that China, the US and India will be the three largest economies in the world by 2050. This growth in China and India has been fueled by an outward-orientated economic policy, which has seen export growth in both countries of over 10 percent per year since the 1980s.

\footnotetext{
*Corresponding address: Kwok Tong Soo, Department of Economics, Lancaster University Management School, Lancaster, LA1 4YX, United Kingdom. Tel: +44 (0) 1524594418. Email: k.soo@lancaster.ac.uk (2008-Center for International Economics, Sejong Institution, All Rights Reserved.
} 
This rapid growth has led to fears especially in the US, that China and India may threaten the livelihood of the people in the developed countries. This sense of a threat is compounded by recent policy incidents, for example the US tariff on steel imports in 2002 and the EU's quota restriction on textile imports in 2005. These fears were given academic support in Samuelson's (2004) Journal of Economic Perspectives paper, as well as in an earlier Journal of Economic Literature paper (Samuelson (2001)), which argued that in a simple Ricardian model of trade based on technological differences across countries, the US may lose from economic growth in China if China becomes more similar to the US in terms of its comparative advantage. That a country can be made worse off by changes that occur in its trading partner(s) poses a conundrum, since it is demonstrably true in the context of the model that Samuelson (2004) sets out, yet at the same time appears to fly in the face of trade economists' gains from trade result.

It should be stressed that the result in Samuelson (2004) that the US may lose from growth in China is merely one of several possibilities; Panagariya (2004) has pointed out that much earlier work by Johnson $(1954,1955)$ had shown that economic growth in a country may lead to lower welfare levels for its trading partner(s). Also, recent work by Jones and Ruffin (2007) using a similar framework to Samuelson (2004) shows that technological transfer from the US to less developed countries in its comparative advantage industries may lead to gains to the US rather than losses. Samuelson's (2004) and Jones and Ruffin's (2007) results may be thought of as reverse immiserising growth of the Bhagwati (1958) type, since in this case growth in the trading partner may harm or benefit the home country, depending on its impact on the terms of trade.

In an extended discussion section, Samuelson (2004) argues that the insight from his simple model can be generalised to richer models. This paper sets out to perform this generalisation. We develop a three-country model based on increasing returns to scale at the level of the firm and monopolistic competition, combined with differences in relative factor endowments and technology across countries, and non-homothetic preferences. In the interest of keeping the model as simple as possible, we impose strong assumptions on the technology side along the lines of Krugman (1981), and we adopt the simplest possible, quasi-linear utility function. The underlying monopolistic competition model is that of Krugman (1980), based on the Dixit-Stiglitz (1977) framework.

In addition to considering Samuelson's result in a more general framework, this paper also differs from the eclectic approach of Markusen (1986). Our setup is 
more tractable than Markusen (1986) yet retains much of the same flavour. Our three-country framework also differs from that of Markusen (1986) as here our three countries may be different from one another, whereas Markusen (1986) focussed on pairs of countries, where countries within each pair are symmetric to one another. Also, of our three countries, we assume that two of them are lessdeveloped countries while the third represents a developed country. This then allows us to explore what happens for example to the rest of the developing world as China and India experience rapid economic growth. The use of nonhomothetic preferences in economic models has a long history, dating back to Linder's (1961) work on international trade between rich and poor countries, and has received empirical validation in Hunter (1991) who showed that nonhomothetic preferences may account for as much as one quarter of interindustry trade flows. More recent empirical evidence by Chung (2002) and Dalgin, Mitra and Trindade (2007) confirms the importance of demand nonhomotheticity in international trade.

The approach used in this paper is also different from that used in Mitra and Trindade (2005) and Chung (2003), which both develop models of international trade with nonhomothetic preferences. Similarly to Mitra and Trindade but differently from Chung, our model incorporates nonhomothetic preferences in a model combining both factor endowment differences and internal scale economies and monopolistic competition. Unlike Mitra and Trindade, our adoption of quasihomothetic preferences means that the model has no implications for the relationship between inequality and trade. We view this as an acceptable tradeoff for the benefit of far greater simplicity in our model, and because our focus is on inter-country rather than intra-country interactions.

Our main finding is that the introduction of nonhomothetic preferences and lovefor-variety coupled with increasing returns, leads to additional channels through which the effects of changes in a trading partner affect a country, in addition to the terms of trade effect identified by Samuelson (2004). First, nonhomothetic preferences generate a home bias in demand despite the absence of transport costs, as the developed country, being relatively abundant in high-wage, high-skill workers, will also have a greater relative demand for high-income-elasticity goods such as electronics which are produced by high-skill workers. As a result, the developed country is insulated to a certain degree from changes in the developing countries.

Second, as the developing countries grow, the increased supply of goods also implies a larger number of varieties available for consumption. Therefore, whilst growth in a developing country may improve or worsen the developed country's 
terms of trade through its impact on world relative supply, there will also be a gain from more varieties because of love-for-variety in consumption, which dampens any negative terms of trade effects of growth in the developing country. Whilst our numerical examples in Section 3 show that the developed country never experiences a welfare loss from the changes in the developing countries, we see these results not as definitive, but rather as indicative of the forces at work.

The model we present in this paper relates to several strands of literature. As it uses a monopolistic competition model, it builds on the insights from Helpman and Krugman (1985). In generating a gravity-type prediction on the volume of trade, it follows work by Anderson (1979) and Krugman (1979, 1980). And finally, in discussing international trade between developed and less developed countries, it is related to the work by Markusen (1986), Flam and Helpman (1987), Stokey (1991), Ramezzana (2000), Matsuyama (2000), Mitra and Trindade (2005), and Chung (2003), among others.

The structure of the rest of this paper is as follows. In the next section, we present the structure of the model, starting with the autarkic equilibrium, then allowing for free trade between the three countries. Section 3 considers the implications for welfare in all three countries when the trading partners experience economic growth. Section 4 concludes.

\section{The Model}

In this section we first describe the autarkic equilibrium of the model, then consider its implications for free trade in goods but not in labour.

\section{A. Autarkic Equilibrium}

The basic setup of the model is that of a monopolistic competition model developed from Krugman (1981), with the main points of departure being the use of non-homothetic preferences and a three-country setup. There are three countries $\mathrm{z}=1,2,3$, and two industries $\mathrm{h}=1,2$. Each industry consists of a large number of products which enter symmetrically into demand. The representative consumer has the following quasi-linear utility function:

$$
U=\ln C_{1}+C_{2}
$$

where each of $C_{h}$ is a composite index of products comprising a constant- 
elasticity-of-substitution (CES) function:

$$
C_{1}=\sum_{i} c_{1 i}^{\theta} \quad C_{2}=\sum_{j} c_{2 j}^{\theta} \quad 0<\theta<1
$$

where $c_{1 i}$ is consumption of the $i$ th product of industry $1^{1}$ and so $\mathrm{on}^{2}$. The value of $\theta$ measures the degree of substitutability among products within an industry. The lower is $\theta$, the more differentiated are products in the industry. Quasi-linear utility implies that consumption of products in both industries initially increases with income, then products in industry 1 have zero income elasticity of demand above a certain income threshold, beyond which all additional income is spent on products in industry 2 . We assume that consumer income always lies beyond this threshold. Beyond this threshold, this function is also quasi-homothetic, so that shifting income between agents does not change the total expenditure on different industries. This allows us to aggregate individual demands.

Each industry is produced using a specific type of labour, so that there are two types of labour $y=1,2$. Type 1 labour is used in industry 1 and type 2 labour in industry 2. Making the labour industry-specific prevents us from considering the redistribution of labour across industries as parameter values change; however it does make the model much easier to solve, and in any case sectoral reallocation of labour is not the main focus of the present paper. There is also substantial evidence that factors of production are not very mobile across sectors; see for example Wacziarg and Wallack (2004) or Lee and Wolpin (2006). Labour is not specific to products within each industry. The cost function for any product in each industry exhibits increasing returns to scale:

$$
l_{1 i}=\alpha+\beta x_{1 i} \quad l_{2 i}=\alpha+\beta x_{2 j} \quad i=1, \ldots, n_{2}
$$

where $l_{1 i}$ is labour used in producing the $i$ th product of industry $1, x_{1 i}$ is the output of that product and so on. Because of increasing returns to scale, consumers'

\footnotetext{
${ }^{1}$ A note on terminology: we use goods and industries interchangeably to indicate broad industry groups, and products and varieties interchangeably to indicate within-industry varieties.

${ }^{2}$ This formulation of the CES function is slightly different from the standard one used in the literature (see e.g. Fujita, Krugman and Venables (1999)). It follows the approach used in Krugman (1980), and generates the same constant-elasticity-of-substitution demand function. The difference between the two, is that the standard approach allows a simpler derivation of the price index, hence may be simpler when considering trade barriers. The present formulation is simpler in the present application where we do not make use of price indices.
} 
preference for variety, and the large number of potential products of each industry, each firm will produce its own unique product.

Total employment in each industry is equal to the sum of employment in each product in that industry. Full employment is assumed. The labour force is exogenously split between the two types of labour. In country 1, the split is as follows:

$$
\sum_{i} l_{1 i}^{1}=L_{1}^{1}=\gamma_{1}-\eta_{1} \quad \sum_{j} l_{2 i}^{1}=L_{2}^{1}=\eta_{1} \quad \gamma_{1}, \eta_{1}>0 \quad \gamma_{1} \geq 2 \eta_{1}
$$

where $L_{y}^{z}$ is the total endowment of labour type y in country z. The parameters $\gamma$ and $\eta$ measure the quantity of the different types of labour. The second constraint on the parameter values indicates that country 1 has more type 1 labour than type 2 labour. This restriction will be dropped when we consider economic growth later on; the present notation is extremely flexible and will allow us to consider changes in the three countries without having to introduce additional notation.

Given these conditions, equilibrium in the model is solved in the standard way. Since all products in an industry enter symmetrically into demand and all firms have identical cost functions, all products in each industry have the same price. From the firm's profit maximisation problem, and noting that the elasticity of demand is $\frac{1}{1-\theta}$, the firm's profit-maximising price is a constant markup over marginal cost:

$$
p_{1 i}=\frac{\beta w_{1}}{\theta} \quad p_{2 j}=\frac{\beta w_{2}}{\theta}
$$

where $p_{1 i}$ is the price of product $i$ in industry 1 and so on.

Free entry and exit of firms ensures that profits are zero in equilibrium. Combining this zero profit condition and the firms' pricing decision allows us to solve for the output (and hence size) of each firm:

$$
x_{1 i}=x_{2 j}=\frac{\alpha}{\beta} \frac{\theta}{1-\theta}=x
$$

Notice that firm sizes are independent of market size. Then the number of firms in each industry can be obtained by combining the full employment condition with the labour endowment and the size of firms:

$$
n_{1}=\frac{\gamma_{1}-\eta_{1}}{\alpha+\beta x} \quad n_{2}=\frac{\eta_{1}}{\alpha+\beta x}
$$


The number of firms is proportional to the labour endowment. Relative prices and wages are determined from the first order conditions of the consumer's maximisation problem:

$$
\left(\sum_{i} c_{1 i}^{\theta}\right)^{-1} \theta c_{1 i}^{\theta-1}=\lambda p_{1 i} \quad \theta c_{2 j}^{\theta-1}=\lambda p_{2 j}
$$

where $\lambda$ is the Lagrange multiplier on the budget constraint or the marginal utility of income. Given our symmetry assumptions, the relative prices are:

$$
\frac{p_{2 j}}{p_{1 i}}=n_{1} c_{1 i}^{\theta}
$$

Equilibrium wages are determined by these prices and the pricing equation (5).

\section{B. Free Trade Equilibrium}

In this subsection we consider what happens when we allow three countries to engage in free international trade in goods but not in labour. Assume identical preferences across countries and free trade in goods but not in labour between countries. To determine the pattern of trade between the three countries, we must first determine the endowment of the two types of labour in each country. Country 1 's endowment is given in the previous subsection. Assume that countries 2 and 3 have the following endowments:

Country 2: $\sum_{i} l_{1 i}^{2}=L_{1}^{2}=\gamma_{2}-\eta_{2} \quad \sum_{j} l_{2 j}^{2}=L_{2}^{2}=\eta_{2}$

Country 3: $\sum_{i} l_{1 i}^{3}=L_{1}^{3}=\eta_{3} \quad \sum_{j} l_{2 j}^{3}=L_{2}^{3}=\gamma_{3}-\eta_{3}$

$$
\gamma_{2}, \eta_{2}, \gamma_{3}, \eta_{3}>0 \quad \gamma_{2} \geq 2 \eta_{2} \quad \gamma_{3} \geq 2 \eta_{3}
$$

where as above $L_{y}^{z}$ is the total endowment of labour type y in country z. The parameters $\gamma$ and $\eta$ measure the similarity of relative endowments across the countries. For example, if $\eta_{z}=0$ for all countries $z$, then each country has only one type of labour and hence can only produce varieties of a single industry. If $\eta_{z}=\gamma_{z}$ $\eta_{z}$, all countries have the same relative endowment ratio. Each country's total endowment is given by $\gamma_{\mathrm{z}}$.

Given the relationship between the endowment parameters $\gamma$ and $\eta$, countries 1 and 2 are relatively well-endowed with type 1 labour compared to country 3 . 
Therefore, Countries 1 and 2 have a comparative advantage in industry 1 and Country 3 in industry 2 . Total world endowment of type 1 labour is equal to $\left(\gamma_{1}-\eta_{1}+\gamma_{2}-\eta_{2}+\eta_{3}\right)$ while the total world endowment of type 2 labour is equal to $\left(\gamma_{3}-\eta_{3}+\eta_{1}+\eta_{2}\right)$.

In this model, changes in endowments and changes in technology are identical in their effects on production but not in their effects on consumption. For example, whilst doubling total endowments may be caused either by a doubling of the number of workers, a doubling of labour productivity, or some combination of the two, changing the number of workers would affect the demand for industry 1 , because of our nonhomothetic preferences, whereas changing labour productivity would not have any impact on the demand for industry 1 , as any additional income will be spent entirely on industry 2 . For the remainder of the paper we hold the number of workers constant and identical across countries and allow productivity to vary across countries; therefore, the labour endowments defined above should be interpreted as efficiency units of labour.

In terms of world trading patterns, the developed countries would be represented by country 3 , which has a comparative advantage (given the constraints on the parameter values) in highly income-elastic goods such as computer software which are produced using skilled labour. The less developed countries correspond to countries 1 and 2, with a comparative advantage in low income elasticity of demand goods such as food and clothing ${ }^{3}$ which are produced using unskilled labour. Our specification allows us to introduce superior technology in the developed countries relative to the less developed countries.

Since preferences are identical across countries, the profit maximising price is the same as in equation (5) above. From the first order conditions for the consumer's problem above, equilibrium price ratios are:

$$
\frac{p_{2 j}}{p_{1 i}}=n_{1}^{W} c_{1 i}^{\theta}
$$

where $n_{1}^{W}$ is the total number of type 1 firms in the world. We normalise $p_{1}=w_{1}=1$ which implies $\beta=\theta$. Prices and wages in industry 2 are pinned down by equation (10). Free trade in goods implies factor price equalisation across countries, measured in efficiency units of labour.

From equations (6) and (7), and making use of the assumption that $\beta=\theta$, the

${ }^{3}$ If we abstract from the quality of these goods. 
total world output of each industry is:

$$
n_{1}^{W} x=\gamma_{1}-\eta_{1}+\gamma_{2}-\eta_{2}+\eta_{3} \quad n_{2}^{W} x=\gamma_{3}-\eta_{3}+\eta_{1}+\eta_{2}
$$

National incomes $Y^{r}$ are equal to:

$$
Y^{1}=\gamma_{1}-\eta_{1}+w_{2} \eta_{1} \quad Y^{2}=\gamma_{2}-\eta_{2}+w_{2} \eta_{2} \quad Y^{3}=\eta_{3}+w_{2}\left(\gamma_{3}-\eta_{3}\right)
$$

Because of the quasi-linear utility function and identical numbers of consumers in each country, each country consumes one-third of the world output of each product of industry 1 ; that is, total expenditure on industry 1 (and total consumption, given our normalisation above) in each country is equal to $\left(\left(\gamma_{1}-\eta_{1}+\gamma_{2}-\eta_{2}+\eta_{3}\right) / 3\right)$. Therefore, we can back out the total expenditure by each country on industry 2 by subtracting expenditure on industry 1 from national income. Appendix A provides details of this calculation.

Defining $X_{h}^{z v}$ as the exports of industry h from country z to country v, we can compute the exports of each country to the other two countries. Because all varieties of a good are symmetric, a country's exports of an industry to another country is equal to the output of the country in that industry multiplied by the fraction of world output that is consumed in the importing country. For country 1 , exports of the two industries to countries 2 and 3 are:

$$
X_{1}^{12}=X_{1}^{13}=\frac{\gamma_{1}-\eta_{1}}{3} \quad X_{2}^{12}=\left(\frac{\eta_{1}}{n_{2}^{W} x}\right) E_{2}^{2} \quad X_{2}^{13}=\left(\frac{\eta_{1}}{n_{2}^{W} x}\right) E_{2}^{3}
$$

where $E_{y}^{z}$ is the expenditure in country z of industry y as defined in Appendix A. Therefore, country 1 exports the same quantity of industry 1 to both countries because of the quasilinear utility and the assumption of identical numbers of consumers in each country, but exports of industry 2 to the two countries are different because national expenditures on industry 2 are determined by national per capita incomes. Country 2's exports to countries 1 and 3 can be obtained analogously.

$$
X_{1}^{21}=X_{1}^{23}=\frac{\gamma_{2}-\eta_{2}}{3} \quad X_{2}^{21}=\left(\frac{\eta_{2}}{n_{2}^{W} x}\right) E_{2}^{1} \quad X_{2}^{23}=\left(\frac{\eta_{2}}{n_{2}^{W} x}\right) E_{2}^{3}
$$

Country 3 's exports to countries 1 and 2 are: 


$$
X_{1}^{31}=X_{1}^{32}=\frac{\eta_{3}}{3} \quad X_{2}^{31}=\left(\frac{\gamma_{3}-\eta_{3}}{n_{2}^{W} x}\right) E_{2}^{1} \quad X_{2}^{32}=\left(\frac{\gamma_{3}-\eta_{3}}{n_{2}^{W} x}\right) E_{2}^{2}
$$

Our primary focus is on the welfare implications of changes in the parameter values for the three countries, but here we briefly comment on the observed trade patterns. Given the parameter restrictions we impose on the endowments, we can see that countries 1 and 2 export more of good 1 relative to good 2 than country 3 . This is as expected, since the parameter restrictions mean that countries 1 and 2 are well-endowed with type 1 labour relative to country 3 . Similarly, country 3 exports more of good 2 relative to good 1 compared to the other countries. There is also significant bilateral trade within the same industry groups. This comes from the love-for-variety, monopolistic competition setup; with no trade barriers across countries, consumers will wish to consume identical amounts of each variety of each good, irrespective of the country of origin of the variety.

All countries gain from trade in this model. Countries experience greater gains from trade the less similar they are in their relative endowments, as larger differences in relative endowments imply larger differences in autarkic relative prices, thus increasing the scope for gains through price changes. Gains from trade are also larger the lower the degree of substitutability between varieties $\theta$, as product differentiation increases and consumers place more weight on variety in consumption. These are as we would expect, and are in line with the results from Krugman (1981).

\section{Economic Growth in the Developing World}

One of the main economic trends in the world today is the rapid economic growth of China and India. More generally, the world consists of developed countries and developing countries. Some of the latter countries are experiencing rapid economic growth whilst others in this category are not. This section makes use of the flexible framework developed in the previous section to explore the welfare implications of various types of growth on the different groups of countries.

We assume that national welfare is simply the sum of individual welfare, making use of the quasi-homotheticity of the utility function to allow for aggregation across individuals with different income levels. Due to the many interactions in the model, we focus on graphical representation of the results. It turns out that for the 
parameters we use below, in free trade good 2 always has a higher price than good 1 as a result of it being the income-elastic good. This also implies higher wages of type 2 labour as compared to type 1 .

\section{A. Analysis}

We begin with all countries symmetric to one another in terms of their endowments; that is, $\gamma_{z}$ and $\eta_{z}$ each identical across countries but allowing $\gamma_{z}$ and $\eta_{z}$ to differ from one another. Consider first the implications of allowing the developed country 3 to have superior technology to countries 1 and 2. In our framework, this can be done by increasing the efficiency units of both types of labour endowment in country 3 in the same proportion, whilst holding the number of consumers constant. Figure 1(a) depicts this change, with country 3's technological level doubling. As expected, superior technology leads to higher welfare in country 3, but it also leads to (marginally) higher welfare in countries 1 and 2, mainly because the expansion of production in all sectors in country 3 raises the real income of countries 1 and 2 by reducing the prices of goods (note that in figures 1(a), 1(b) and 1(e), because countries 1 and 2 are identical to one another, the welfare of countries 1 and 2 are identical so that only the welfare of country 2 is visible).

Given the assumption that country 3 is technologically superior to countries 1 and 2, we can explore what happens to welfare in the three countries when several things happen, holding country 3 unchanged:

1. Technological improvement in countries 1 and 2 in both sectors; technological catch-up with country 3 (Figure 1(b))

2. Technological improvement only in country 1 in both sectors (Figure 1(c))

3. Technological improvement in only one sector of country 1 (here, consider sector 1 of country 1) (Figure 1(d))

4. Countries 1 and 2 experience a change in endowments through a shift from type 1 labour (unskilled) to type 2 labour (skilled); endowment convergence with country 3 (Figure $1(\mathrm{e})$ )

5. Endowment convergence of only country 1 to country 3 (Figure 1(f))

Figures 1(b) to 1(f) show all of these changes. Table 1 lists the parameter values for which each figure is drawn; the column headings correspond to final parameter values for each figure. What is immediately obvious from these figures is that country 3 (the developed country) never experiences a welfare loss regardless of what happens in the two developing countries. This result holds for many 
Figure 1. Utility under the various cases.
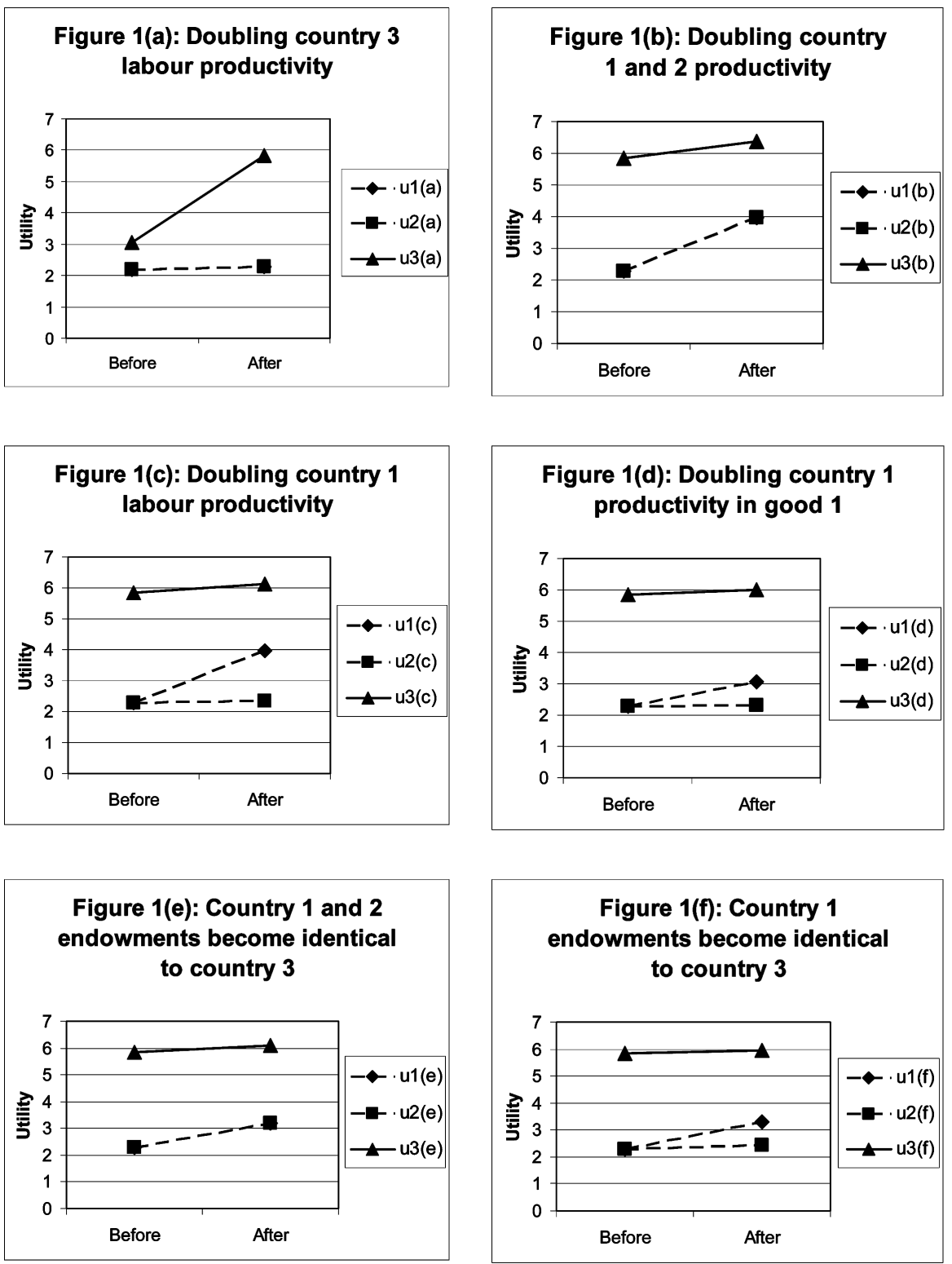

alternative parameter values, but we do not wish to argue that this is a general result; rather, we use this finding to explore the economic forces at work.

Intuitively, if the change in countries 1 and 2 imply expansion of world relative supply of good 1, this is a gain to country 3 as it is a net importer of this good, so its consumers benefit from lower relative prices of imports. On the other hand, if 
Table 1. Parameter values for Figure 1.

\begin{tabular}{ccccccccc}
\hline Variable & $\begin{array}{c}\text { Initial value for } \\
1(\mathrm{a})\end{array}$ & 1(a) & $\begin{array}{c}\text { Initial value for } \\
1(\mathrm{~b})-1(\mathrm{f})\end{array}$ & $1(\mathrm{~b})$ & $1(\mathrm{c})$ & $1(\mathrm{~d})$ & $1(\mathrm{e})$ & $1(\mathrm{f})$ \\
\hline$\gamma_{1}$ & 2 & 2 & 2 & 4 & 4 & 3.5 & 2 & 2 \\
$\eta_{1}$ & 0.5 & 0.5 & 0.5 & 1 & 1 & 0.5 & 1.5 & 1.5 \\
$\gamma_{2}$ & 2 & 2 & 2 & 4 & 2 & 2 & 2 & 2 \\
$\eta_{2}$ & 0.5 & 0.5 & 0.5 & 1 & 0.5 & 0.5 & 1.5 & 0.5 \\
$\gamma_{3}$ & 2 & 4 & 4 & 4 & 4 & 4 & 4 & 4 \\
$\eta_{3}$ & 0.5 & 1 & 1 & 1 & 1 & 1 & 1 & 1 \\
$\theta$ & 0.8 & 0.8 & 0.8 & 0.8 & 0.8 & 0.8 & 0.8 & 0.8 \\
$\alpha$ & 0.02 & 0.02 & 0.02 & 0.02 & 0.02 & 0.02 & 0.02 & 0.02 \\
$\beta$ & 0.8 & 0.8 & 0.8 & 0.8 & 0.8 & 0.8 & 0.8 & 0.8 \\
\hline
\end{tabular}

the change in countries 1 and 2 imply expansion of world relative supply of good 2 , this benefits country 3 as well because it remains the largest consumer of good 2 due to its high per capita income, and expanded world supply of good 2 increases the number of varieties of good 2 available, hence raising consumer welfare even whilst its terms of trade erodes as a result of this growth in countries 1 and 2.

In the cases when countries 1 and 2 grow simultaneously and symmetrically (cases 1 and 4 above, corresponding to figures 1(b) and 1(e)), both growing countries benefit from this change. Clearly, superior overall productivity benefits the country, as does a shift towards greater endowments of factors which yield output which have high income elasticity of demand. ${ }^{4}$ In addition, in the figures, if only one developing country grows (country 1 in every case) and the other (country 2) does not, the country that does not grow also experiences a welfare improvement, albeit a marginal one.

This improvement in the welfare of country 2 when country 1 grows arises because, if the change in country 1 is such that world relative supply of good 1 increases (e.g. as a result of technological improvement in sector 1, case 3 above or Figure 1(d)), the welfare gain from the increase in the number of varieties of good 1 available for consumption outweighs the welfare loss from the fall in the relative price of good 1 . On the other hand, if the change in country 1 increases world supply of good 2 and decreases world supply of good 1, then it turns out that the gain in welfare from country 2 consumers consuming more of good 2 outweighs the loss of welfare from the lower consumption of good 1, as a result of the quasi-linear

\footnotetext{
${ }^{4}$ Immiserising growth of the Bhagwati (1958) type does not occur, because no country's offer curve is inelastic (see Bhagwati, Panagariya and Srinivasan (1998) p. 377).
} 
preferences which place a greater weight on consumption of good 2. There is also a gain from the increased number of varieties of good 2 available for consumption.

Therefore, there are essentially three forces at work in determining the welfare effects of any change in the three countries. First, each of the changes leads to a change in world relative supply of the two goods. This affects world relative prices and hence real incomes of each of the three countries. Second, there is the nonhomothetic utility function which leads to a home bias in consumption since less developed countries are relatively abundant in factors of production which are used in producing goods with low income elasticity of demand, and these countries also demand relatively more of the income-inelastic goods, because of their relatively low per capita income. The third force at work is the love of variety in consumption. An increase in world supply of a good, implies an increase in the number of varieties available for consumption, which raises welfare even in the face of declining real income. The second and third forces act to dampen any possible terms of trade losses from changes in a country's trading partners.

\section{Discussion and Conclusions}

Can the growth of a trading partner harm a country? This paper seeks to answer this question by developing a model of international trade between three countries that takes into account elements of factor endowment differences across countries, intra-industry trade of the Dixit-Stiglitz type, and non-homothetic preferences. Although the model seeks to capture all of these important features of international trade, the use of simple functional forms allows us to consider several different ways in which countries can grow, and how this growth impacts on the welfare of both the growing country and its trading partners. Our key result is that the additional elements of our model relative to Samuelson (2004) generate a home bias in demand (from nonhomothetic preferences) and a new channel through which countries gain from trade (from love-for-variety). These additional effects serve to dampen any negative effects on a country of economic growth in its trading partners. Depending on the parameter values, it may even be the case that countries can never lose from growth in their trading partners.

Comparing our results to those of Samuelson (2004), when the trading partner experiences technological improvement in Samuelson's (2004) model in the home (developed) country's import-competing good, this harms the home country because it makes countries more similar and hence reduces the gains from trade 
which arise from differences across countries. This does not happen in our model, because the developed country, having a higher per-capita income, also demands more of the good which uses intensively its abundant factor. Therefore, when its trading partners become more similar to it in terms of endowments, the developed country actually gains from this change because its consumers benefit from having more varieties of the good at lower prices due to the increased supply.

On the other hand, we would get the opposite results if we perform the same thought experiment as Jones and Ruffin (2007). In their paper, the partner country becomes so good at producing the developed country's initial comparative advantage good that the developed country switches its production to the other good, in which it now has a comparative advantage. If the swing in relative comparative advantage is sufficiently large, the developed country may gain from this change. The equivalent experiment in the context of our model would be the case where the developed country acquires more of type 1 labour at the same time as the less developed country acquires more of type 2 labour. In this case, the developed country clearly loses, as its endowment mix shifts towards the low-wage type 1 labour, reducing national income.

The additional elements of our model change the implications of developing country growth on developed country welfare. However, as Jones and Ruffin (2007) note, what may be of concern to governments might not be absolute welfare and income levels, but welfare and income levels relative to those of other countries. Economic growth in less developed countries leads to a narrowing of the relative income gap between rich and poor countries, hence may be a cause for concern in rich countries even if their absolute welfare increases at the same time.

The use of an explicit three-country framework is also a relatively new development in a field that has been largely driven by two-country frameworks ${ }^{5}$. In this case, a three-country approach enables us to explore the interdependencies between countries when their trading partners grow. There exists the possibility of conflict between countries, as changes in one country may impact on other countries in different ways depending on the structure of each country's economy. This again is not inconsistent with the conflicts in international trade that have been observed between different countries.

Received 22 January 2007, Accepted 17 October 2007

${ }^{5}$ See for instance Markusen and Venables (2007) for a discussion of the limitations of the two-country approach. 


\section{Acknowledgments}

Thanks to Holger Breinlich, Dimitra Petropoulou, Julia Shvets, seminar participants at Lancaster University, Universiti Malaya and the European Trade Study Group 2005 in Dublin, and an anonymous referee for valuable comments and suggestions. The usual disclaimer applies.

\section{References}

Anderson, James E. (1979), “A Theoretical Foundation for the Gravity Equation”, American Economic Review, 69(1): 106-116.

Bhagwati, Jagdish N. (1958), "Immiserizing Growth: A Geometrical Note", Review of Economic Studies, 25(3): 201-205.

Bhagwati, Jagdish N., Arvind Panagariya and T. N. Srinivasan (1998), Lectures on International Trade, 2nd edition, Cambridge, MA, MIT Press.

Chung, Chul (2002), "Nonhomothetic Preferences and the Home Market Effect: Does Relative Market Size Matter?", mimeo, Georgia Institute of Technology.

Chung, Chul (2003), "Factor Content of Trade: Nonhomothetic Preferences and "Missing Trade", mimeo, Georgia Institute of Technology.

Dalgin, Muhammed, Devashish Mitra and Vitor Trindade (2007), "Inequality, Nonhomothetic Preferences, and Trade: A Gravity Approach", forthcoming, Southern Economic Journal.

Dixit, Avinash K. and Joseph E. Stiglitz (1977), "Monopolistic Competition and Optimum Product Diversity", American Economic Review, 67(3): 297-308.

Flam, Harry and Elhanan Helpman (1987), "Vertical Product Differentiation and NorthSouth Trade", American Economic Review, 77(5): 810-822.

Fujita, Masahisa, Paul Krugman and Anthony Venables (1999), The Spatial Economy, Cambridge, MA, MIT Press.

Helpman, Elhanan and Paul R. Krugman (1985), Market Structure and Foreign Trade, Cambridge, MA, MIT Press.

Hunter, Linda (1991), "The Contribution of Nonhomothetic Preferences to Trade", Journal of International Economics, 30(3-4): 345-358.

Johnson, Harry G. (1954), "Increasing Productivity, Income-Price Trends and the Trade Balance", Economic Journal, 64(255): 462-485.

Johnson, Harry G. (1955), "Economic Expansion and International Trade", Manchester School of Economic and Social Studies, 23(2): 95-112.

Jones, Ronald W. and Roy J. Ruffin (2007), "International Technology Transfer: Who Gains and Who Loses?", Review of International Economics 15(2): 209-222.

Krugman, Paul R. (1979), "Increasing Returns, Monopolistic Competition, and International Trade", Journal of International Economics, 9(4): 469-479. 
Krugman, Paul R. (1980), "Scale Economies, Product Differentiation, and the Pattern of Trade", American Economic Review, 70(5): 950-959.

Krugman, Paul R. (1981), "Intraindustry Specialization and the Gains from Trade", Journal of Political Economy, 89(5): 959-974.

Lee, Donghoon and Kenneth I. Wolpin (2006), "Intersectoral Labor Mobility and the Growth of the Service Sector", Econometrica 74(1): 1-46.

Linder, Steffan Burenstam (1961), An Essay on Trade and Transformation, New York, Wiley.

Markusen, James R. (1986), "Explaining the Volume of Trade: An Eclectic Approach", American Economic Review, 76(5): 1002-1011.

Markusen, James R. and Anthony J. Venables (2007), "Interacting factor endowments and trade costs: a multi-country, multi-good approach to trade theory", forthcoming, Journal of International Economics.

Matsuyama, Kiminori (2000), "A Ricardian Model with a Continuum of Goods under Nonhomothetic Preferences: Demand Complementarities, Income Distribution, and North-South Trade", Journal of Political Economy, 108(6): 1093-1120.

Mitra, Devashish and Vitor Trindade (2005), "Inequality and Trade", Canadian Journal of Economics, 38(4): 1253-1271.

Panagariya, Arvind (2004), "Why the Recent Samuelson Article is NOT about Offshore Outsourcing" mimeo, Columbia University.

Ramezzana, Paolo (2000), "Per Capita Income, Demand for Variety, and International Trade: Linder Reconsidered", Centre for Economic Performance Discussion Paper No. 460.

Samuelson, Paul A. (2001), "A Ricardo-Sraffa Paradigm Comparing Gains from Trade in Inputs and Finished Goods", Journal of Economic Literature, 39(4): 1204-1214.

Samuelson, Paul A. (2004), "Where Ricardo and Mill Rebut and Confirm Arguments of Mainstream Economists Supporting Globalization", Journal of Economic Perspectives, 18(3): 135-146.

Stokey, Nancy L. (1991), "The Volume and Composition of Trade Between Rich and Poor Countries", Review of Economic Studies, 58(1): 63-80.

Wacziarg, Romain and Jessica Seddon Wallack (2004), "Trade Liberalization and Intersectoral Labor Movements", Journal of International Economics, 64(2): 411439.

Wilson, Dominic and Roopa Purushothaman (2003), "Dreaming with BRICs: The Path to 2050”, Goldman Sachs Global Economics Paper No. 99. 


\section{Appendix A: National Expenditures on Good 2}

This Appendix provides the algebraic expressions for the national expenditures on good 2. Define national expenditure of country z on industry $2, E_{2}^{z}$ as national income less expenditures on industry 1 . Then, this may be written as:

$$
\begin{aligned}
E_{2}^{1} & =Y^{1}-E_{1}^{1}=\gamma_{1}-\eta_{1}+w_{2} \eta_{1}-\frac{\gamma_{1}-\eta_{1}+\gamma_{2}-\eta_{2}+\eta_{3}}{3} \\
& =\frac{1}{3}\left(2 \gamma_{1}-2 \eta_{1}-\gamma_{2}+\eta_{2}-\eta_{3}+3 w_{2} \eta_{1}\right) \\
E_{2}^{2} & =Y^{2}-E_{1}^{2}=\gamma_{2}-\eta_{2}+w_{2} \eta_{1}-\frac{\gamma_{1}-\eta_{1}+\gamma_{2}-\eta_{2}+\eta_{3}}{3} \\
& =\frac{1}{3}\left(2 \gamma_{2}-2 \eta_{1}-\gamma_{1}+\eta_{1}-\eta_{3}+3 w_{2} \eta_{2}\right) \\
E_{2}^{3} & =Y^{3}-E_{1}^{3}=\eta_{3}+w_{2}\left(\gamma_{3}-\eta_{3}\right)-\frac{\gamma_{1}-\eta_{1}+\gamma_{2}-\eta_{2}+\eta_{3}}{3} \\
& =\frac{1}{3}\left(2 \eta_{3}-\gamma_{1}+\eta_{1}-\gamma_{1}+\eta_{2}+3 w_{2}\left(\gamma_{3}-\eta_{3}\right)\right)
\end{aligned}
$$

